\title{
INTRODUCTION TO MODELLING SIDE IED EXPLOSION INFLUENCE ON SPECIAL MILITARY VEHICLE
}

\author{
Wiesław Barnat, Grzegorz Sławiński, Grzegorz Moneta, Robert Panowicz \\ Military University of Technology \\ Department of Mechanics and Applied Computer Science \\ Gen. Sylwestra Kaliskiego Street 2, 00-908 Warsaw, Poland \\ tel.: +4822 6837201, +4822 6837152, +4822 6839683, fax: +48226839355 \\ e-mail:wbarnat@wat.edu.pl,gslawinski@wat.edu.pl,rpanowicz@wat.edu.pl
}

\begin{abstract}
One of the most endangering and challenging threats during recent warfare are explosions of Improvised Explosive Devices (IED) and their destructive influence on a light armoured vehicle. Providing sufficient protection is the most challenging issue which can be achieved thanks to complex studies and a proper design process. The article presents preliminary numerical analyses of side explosion near a special military vehicle with regards to newdeveloped standards. The results were used to modify the existing hull and enhance its protection capabilities against critical charge to provide better protection for personnel inside the vehicle. A numerical model was developed in LSPrePost software. All the computational analyses were carried out using an explicit LS-Dyna solver, where material properties of finite elements were described by the Johnson-Cook material model with the basic parameters specified in the standard tensile tests. Due to time consuming simulations, the Linux-based computational cluster was adopted. The setup (mass of the explosive, distance between explosive charge and vehicle, etc.) was taken from military codes. In their computational research, the authors performed also a kind of a sensitivity study changing some of parameters. Pressure, stress distribution and plastic deformations vehicle structure were analyzed.
\end{abstract}

Keywords: special military vehicle, improvised explosive devices, blast wave, numerical study

\section{Introduction}

The formal basis to propose ballistic limit is NATO STANAG 4569. Companies that produce armoured vehicles for military applications constantly search for better materials with enhanced ballistic performance and energy absorbing. That ensures maximum safety level against IED threats [1]. After the detonation, with regards to explosive type and size, both blast wave and fragments impact on sides and bottom of the hull.

Enhancing survivability and personnel protection are consistent with operational capabilities that should be achieved by Polish Army within next few years. For that reason research centres and defence industry use new techniques of design and advanced numerical analyzes to find best energy-absorbing solutions enhancing passive safety of crew. Investment into new innovative technologies allows gaining new, currently unknown, possibilities that can significantly change the future battlefield during operations such:

- normal warfare,

- in the areas of terrorism,

- fighting against troops fighting in irregular manner,

Armies of most European countries have Light-Armoured-Vehicles designed to transport patrol consisting of 4 or 5 soldiers. Some of them are based on US HMMWV vehicle or its chassis for example Swiss EAGLE or Turkish OTOCAR. However, missions in Afghanistan revealed a number of threats which showed that such solutions are insufficient. Polish Army bought and introduced Wheeled Armoured Vehicle KTO. There are also new constructions such as MRAP vehicle $[2,3]$ introduced and developed by United States Army. Despite the fact that modern and 
robust construction performs well against antitank mines and missiles, it still cannot protect effectively against IED threats [4-7].

Wheeled armoured vehicle to for reconnaissance and mine clearance SHIBA is a modern special vehicle that has proper shaped hull and is equipped to neutralize IED threat. It can both use mine flail or ground-penetrating radar with interrogation arm allowing detection and neutralization of a treat.

\section{Physical model}

The paper presents the results of preliminary numerical analysis of IED blast wave impact on side of special vehicle according to developed standardization.

Among all available methods for numerical analysis, Finite Element Method (FEM) was chosen with explicit scheme of integration implemented in LS-DYNA software $[8,9]$ In such an algorithms the equilibrium equation (1) is solved by direct integration over time. Those equations are coupled which raises numerical cost and demands big memory resources.

Due to short duration of the phenomenon, damping can be omitted. Basic equation in explicit method is [8]:

$$
[M]\{\ddot{x}\}_{n}=\{F\}_{n}-\left\{F_{\text {int }}\right\}_{n},
$$

where:
$[M]$ - mass matrix,
$\{F\}$ - external forces matrix,
$\left\{F_{\text {int }}\right\}$ - internal forces matrix.

Assuming that the mass matrix is diagonal, equations of motion can be solved using explicit Euler method. In that case, nodal acceleration vector $\{\ddot{x}\}$ can be found as [8]:

$$
\{\ddot{x}\}_{n}=[M]^{-1}\left(\{F\}_{n}-\left\{F_{\text {int }}\right\}\right)_{n} .
$$

Equation (2) can also take into account damping, however, only in diagonal form. The main advantage of such an approach is uncoupling differential equations of motion that allows their solving.

Velocity $\{\dot{x}\}_{n+1 / 2}$ and displacement $\{x\}_{n+1}$ vectors for subsequent time steps are obtained by integration [8]:

$$
\begin{gathered}
\{\dot{x}\}_{n+1 / 2}=\{\dot{x}\}_{n-1 / 2}+\{x\}_{n} \Delta t_{n}, \\
\{x\}_{n+1}=\{x\}_{n}+\{\dot{x}\}_{n+1 / 2} \Delta t_{n+1 / 2} .
\end{gathered}
$$

Unfortunately, the method is only stable when time step of integration is limited (4):

$$
\Delta T \leq 2 / \omega_{\max },
$$

where $\omega_{\max }$ is highest natural frequency of discrete model. It means that the time step has to be shorter than time of sound wave propagation through the smallest element in entire model. As a consequence, the more accurate model is used (smaller elements) the shorter time step becomes and time of computation increases. Numerical description of material must also take into account specific properties such as physical state, ductility, brittleness and hardness. All the experimental data were obtained from literature and experimental reports from Department of Mechanics and Applied Computer Science.

\section{Discretization of geometrical model}

Vehicle's hull was meshed in discretization process. Flat, 4-node, elements type Shell [5], were use in order to obtain satisfactory results. Only hull without any additional equipment was taken 
into account during modelling process.

The load was applied according to designed standardization. The charge was placed at $5 \mathrm{~m}(\mathrm{X})$ distance from side of the hull, $1 \mathrm{~m}(\mathrm{H})$ above the ground. The situation is depicted in Fig. 1.

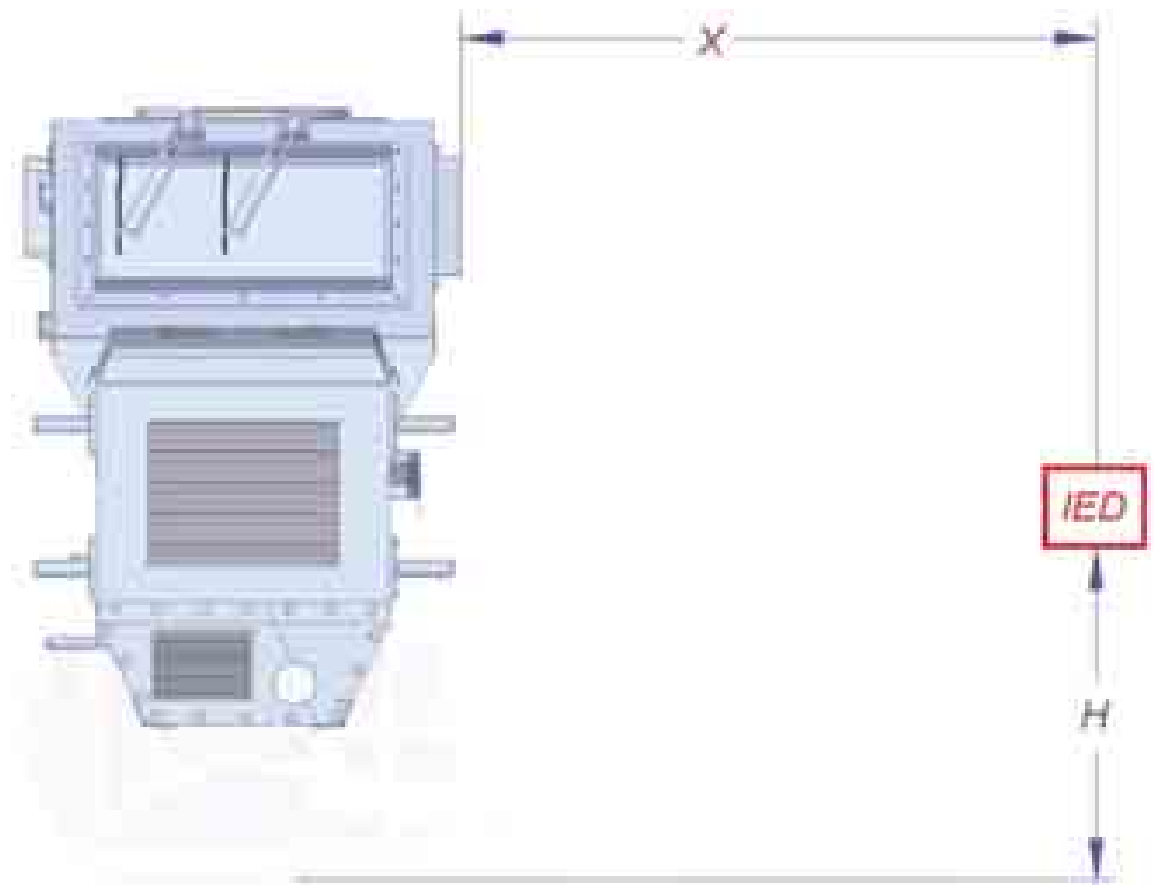

Fig. 1. IED placement

The analysis was conducted for different charge masses: 5, 50, 100, 150, 250 and $500 \mathrm{~kg}$.

\section{Analysis results}

The results obtained for all cases are shown in Fig. 2-5. They show deformations of and internal energy versus time, velocity versus time, displacement of specific points versus time plots.

Figure 2 shows final deformation stages for each explosive charge size. According to the standardization, safe hull should provide enough space inside to allow survival of personnel. This factor can measure reliability of entire structure. The analysis showed that for smaller charges there is enough space inside, whereas for larger ones the deformation may be harmful to crew inside. In order to improve the situation, it is necessary to stiffen the construction.

Basing on the results, numerical model of special vehicle was modified by adding stiffening. Then, the analysis with identical boundary and initial conditions was carried. Deformations in case are shown in Fig. 3. Stiffening decreased plastic deformations and therefore enhanced safety level of personnel inside special vehicle.

As already mentioned, the change of distance between opposite Hull walls determines the crew safety when IED explosion occurs. Comparison of wall-to-all distance versus time with and without stiffening is shown in Fig. 4. Maximum wall displacement was observed in model without stiffening. Hull width decreases 2 times during the explosion.

Besides wall-to-wall distance there are also other factors which are harmful to the crew. Large accelerations affecting personnel can lead to injuries that can exclude them from further combat. Determining accelerations affecting the vehicle and crew inside give significant information how to improve safety level. Acceleration versus time plots for all cases are shown in Fig. 5.

Analysis showed that charges above $100 \mathrm{~kg}$ are extremely dangerous to the crew. When blast wave reaches hull, the pressure peak of short duration occurs. Decreasing the acceleration impulse greatly decreases chances of permanent injuries to the crew. 
a)

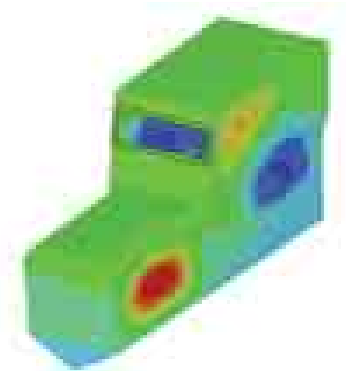

c)

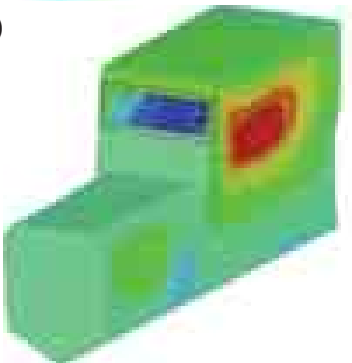

e)

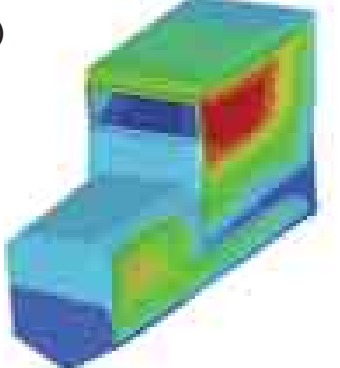

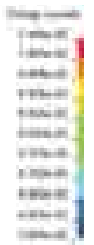
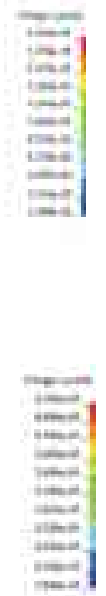

b)

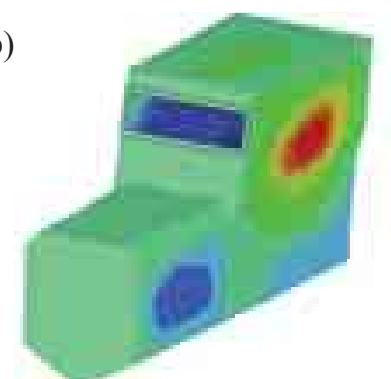

d)

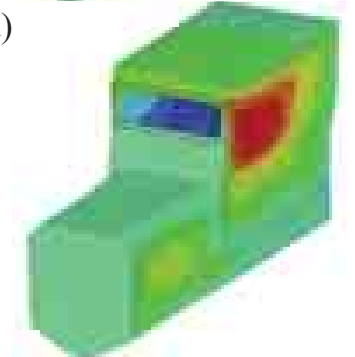

f)

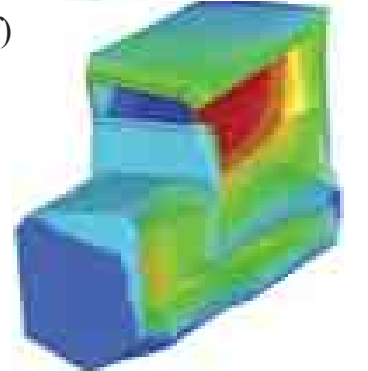

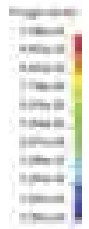

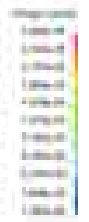

$=1$
$=1$
$=1$
$=1$

Fig. 2. Final displacement stages for IED charges: $25 \mathrm{~kg}(\mathrm{a}), 50 \mathrm{~kg}$ (b), $100 \mathrm{~kg}$ (c), $150 \mathrm{~kg}(\mathrm{~d}), 250 \mathrm{~kg}(\mathrm{e}) 500 \mathrm{~kg}$, (f) $500 \mathrm{~kg}$ without stiffening

a)

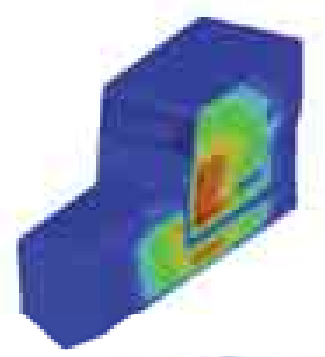

c)

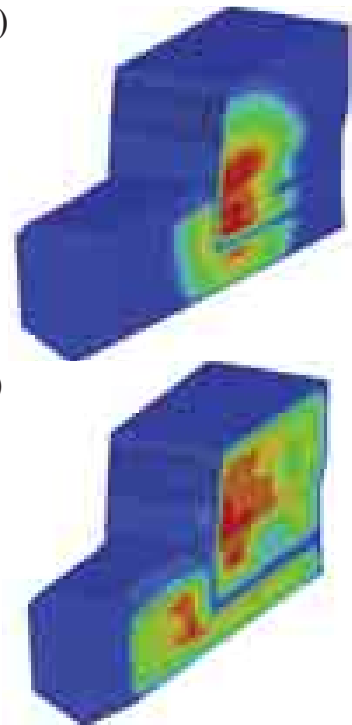

b)
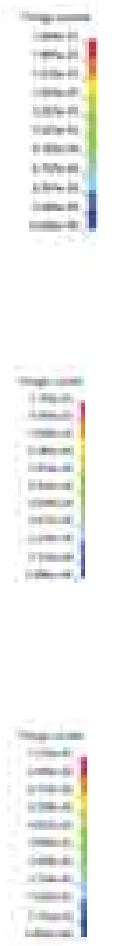

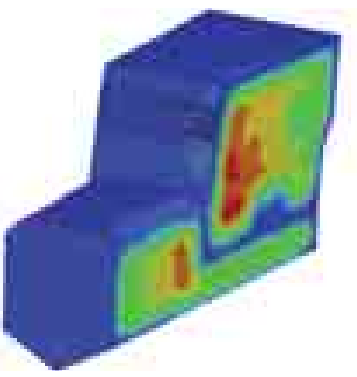

d)

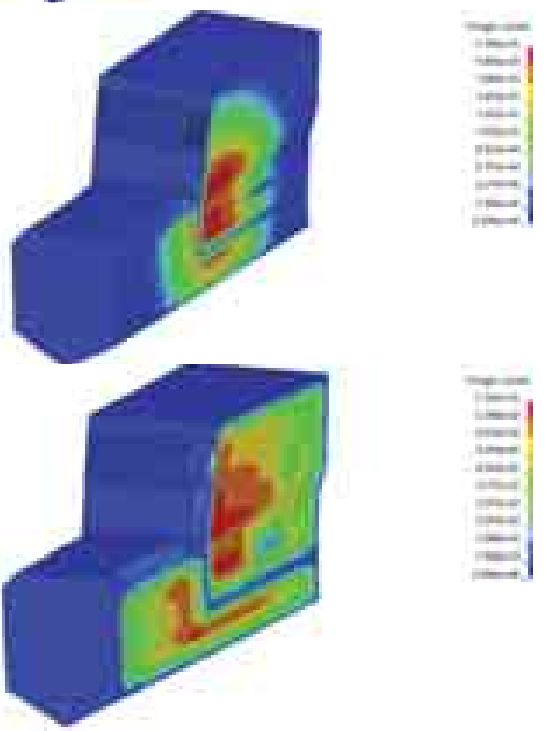

Fig. 3. Final displacement stages for IED charges $25 \mathrm{~kg}$ (a), $50 \mathrm{~kg}$ (b), $100 \mathrm{~kg}$ (c), $150 \mathrm{~kg}$ (d), $250 \mathrm{~kg}(\mathrm{e}) 500 \mathrm{~kg}$, (f) $-500 \mathrm{~kg}$ with stiffening 

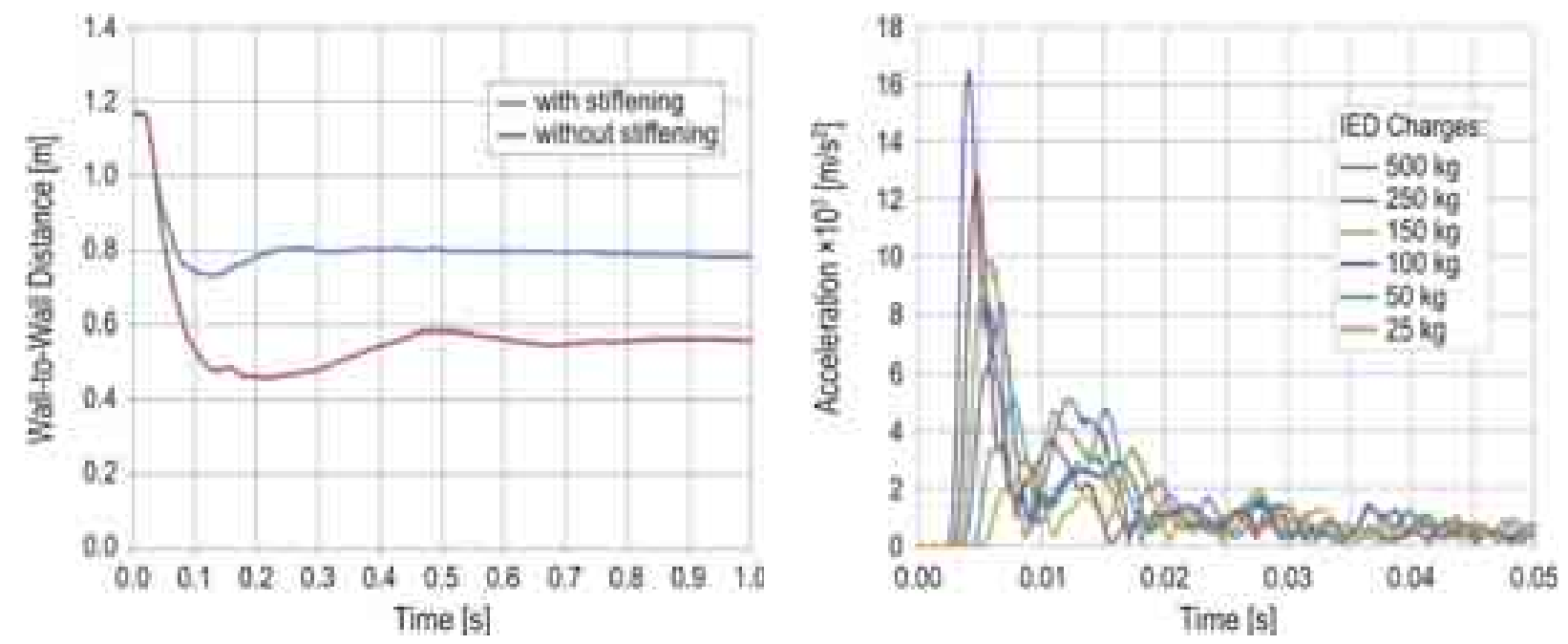

Fig. 4. Wall to wall distance vs. time plot - with andFig. 5. Acceleration versus time plots for all cases with without stiffening

stiffening

\section{Summary}

Polish Army must keep up with current and predicted armament innovations, especially within NATO pact, in order to meet the demands of modern battlefield. One of the issues is providing proper safety level for vehicle's crew against Improvised Explosive Devices.

Numerical simulations of blast wave impact are one of the most important parts of modern design process. They are cheaper than experimental trials and allow rapid modification and optimization of shape.

Improvised Explosive Devices are the most harmful threats during peacekeeping missions. Pressure impulse and fragments can cause serious injuries and even death in only fww milliseconds. Providing sufficient safety level of military vehicles is one of the most important issues for modern military vehicles.

\section{Acknowledgement}

The paper is a part of a development project No. O R00 0081 12, entitled: Group of modular wheeled armoured vehicles for reconnaissance and mine clearance of roads, supported by Ministry of Science and Higher Education, Poland. This support is gratefully acknowledged.

\section{References}

[1] Barnat, W., Numeryczno doświadczalna analiza złożonych warstw ochronnych obciążonych fala uderzeniowa wybuchu, Bell Studio, 2009.

[2] Garstka, J., Czy MRAP-y zastapia LOSP-y, Bellona, 1/2009.

[3] Kupidura, P., Charakterystyka pojazdów MRAP Cougar oraz wnioski z ich eksploatacji $w W P$, Problemy Techniki Uzbrojenia, 2/2009.

[4] Trzciński W., Trębiński R., Cudziło S., Investigation of the Behaviour of Steel and Laminated Fabric Plates Under Blast Wave Load, Part I: Experimental Approach, V International Armament Conference, Waplewo 2005.

[5] Jakubowski, R., Ofiary wojny - okupacja Iraku 2003 - 2009, Raport Wojsko Technika Obronność, Warszawa 2009.

[6] Kania, E., Projektowanie środków ochrony przeciwminowej pojazdów specjalnych, Górnictwo Odkrywkowe, 4/2010. 
[7] Mężyk, A., Nowoczesne technologie w projektowaniu pojazdów specjalnych, 66 Inauguracja Roku Akademickiego w Politechnice Śląskiej, Gliwice 2010.

[8] Ls Dyna Theory Manual, Livemore, CA 2005.

[9] Baker, W. E., Explosions in Air, University of Texas Press, Austin and London 1973. 